〈報 告〉

\author{
擦式アルコール手指消毒薬の使用率向上による細菌分離率の低下 \\ 村田 明子 ${ }^{122}$ ・ 川嶋 郁 ${ }^{2)}$ 畠山 英司 ${ }^{1,2)}$ \\ 山㟝 彩華 ${ }^{1,2)} \cdot$ 松本 勝城 ${ }^{1,2)} \cdot$ 深沢 貴志 ${ }^{1,2}$

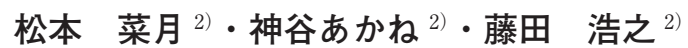

\title{
Reduction in Bacterial Isolation Rate with Improved Compliance for the Use of Alcohol-based Hand Rub
}

\author{
Akiko Murata ${ }^{1,2)}$, Kaoru KaWAShimA ${ }^{2)}$, Eiji Hatakeyama ${ }^{1,2)}$, \\ Ayaka YAmAZAKI ${ }^{1,2)}$, Katsuki MATSUMOTO ${ }^{1,2)}$, Takashi FuKASAWA ${ }^{1,2}$, \\ Natsuki Matsumoto ${ }^{2)}$, Akane KamiYa ${ }^{2)}$ and Hiroyuki Fujita ${ }^{2)}$ \\ ${ }^{1)}$ Department of Pharmacy, Saiseikai Yokohamashi Nanbu Hospital, ${ }^{2)}$ Infection Control Team, Saiseikai Yokohamashi Nanbu Hospital
}

(2019 年 10 月 6 日受付 $\cdot 2020$ 年 4 月 27 日受理)

要旨

擦式アルコール手指消毒薬の消費量が医療関連感染との関連性が深いメチシリン耐性黄色ブドウ

球菌（MRSA）, Serratia marcescens, 基質特異性拡張型 $\beta$ ラクタマーゼ（ESBL）産生大腸菌の 検出率と関連がみられるかを後方視的に検討した．擦式アルコール手指消毒薬使用量を増加させる ために, 2014 年より病棟ラウンドで個々の看護師に対して手指衛生の手法に関する直接指導を行 い, 院内感染防止をテーマとして勉強会を実施した。 その結果, 手指消毒薬使用率 (L/1,000patientdays）は取り組み前後において，一般病棟では 4.42 から 11.0, クリティカル部門では 19.5 から 65.3 と増加した. MRSA 分離率（分離数/1,000patient-days）は，一般病棟では 0.58 から $0.35 （ \mathrm{p}<0.05$ ), クリティカル部門では 4.57 から 3.40 へ減少した. Serratia marcescens 分離率は, 一般病棟では 0.08 から 0.06 , クリテイカル部門では 1.37 から $0.13(\mathrm{p}<0.05)$ 一減少した. ESBL 産生大腸菌分離率 は一般病棟では 0.17 から 0.13 , クリティカル部門では 0.46 から 0.38 へ減少した.

これらの細菌分離率を低く抑えるために, 看護師への教育を引き続き続けるとともに，すべての 職種に対して手指消毒薬の消費を促したいと考えている.

Key words：手指消毒，擦式アルコール手指消毒薬，MRSA，細菌分離率

序文

手指衛生は医療関連感染防止対策の 1 つとして重要で ある ${ }^{1 \sim 3)}$. 世界保健機関 (World Health Organization : WHO）では，医療関連感染や多剂耐性菌の広がりを防 ぐために手指衛生は不可欠としている゙．職員に対する 啓発活動や手洗い環境の整備を行うことにより手指消毒 薬の使用量が増加すると報告されている5).

院内感染の原因菌として知られるメチシリン耐性黄色 ブドウ球菌 (Methicilin-resistant Staphylococcus

1) 済生会横浜市南部病院薬剤部, 2) 済生会横浜市南部病院感染制御 チーム
aureus：MRSA）は，多くの抗菌薬に耐性であり菌血 症やデバイス感染, 皮虐軟部組織感染を起こすと重篤化 することが多い。これまでにも, MRSA 分離率減少や MRSA 感染症の発症減少には, 手指消毒薬の使用量増 加が関連して㧍り，擦式アルコール手指消毒薬の個人携 帯開始や使用量の個人へのフィードバック等が重要であ るとの報告がある ${ }^{6 \sim 8)}$. また, MRSA, 腸球菌, O157, Serratia marcescens, 緑膿菌㧍よび Burkholderia cepacia に対して, 手指消毒薬の種類による除菌効果の差が検討 され，クロルヘキシジン製剤やヨードホール製剤では短 時間の作用で除菌効果が得られたとの報告がある ${ }^{9}$. し かしながら，こうした手指消毒遵守と MRSA 以外の臨 


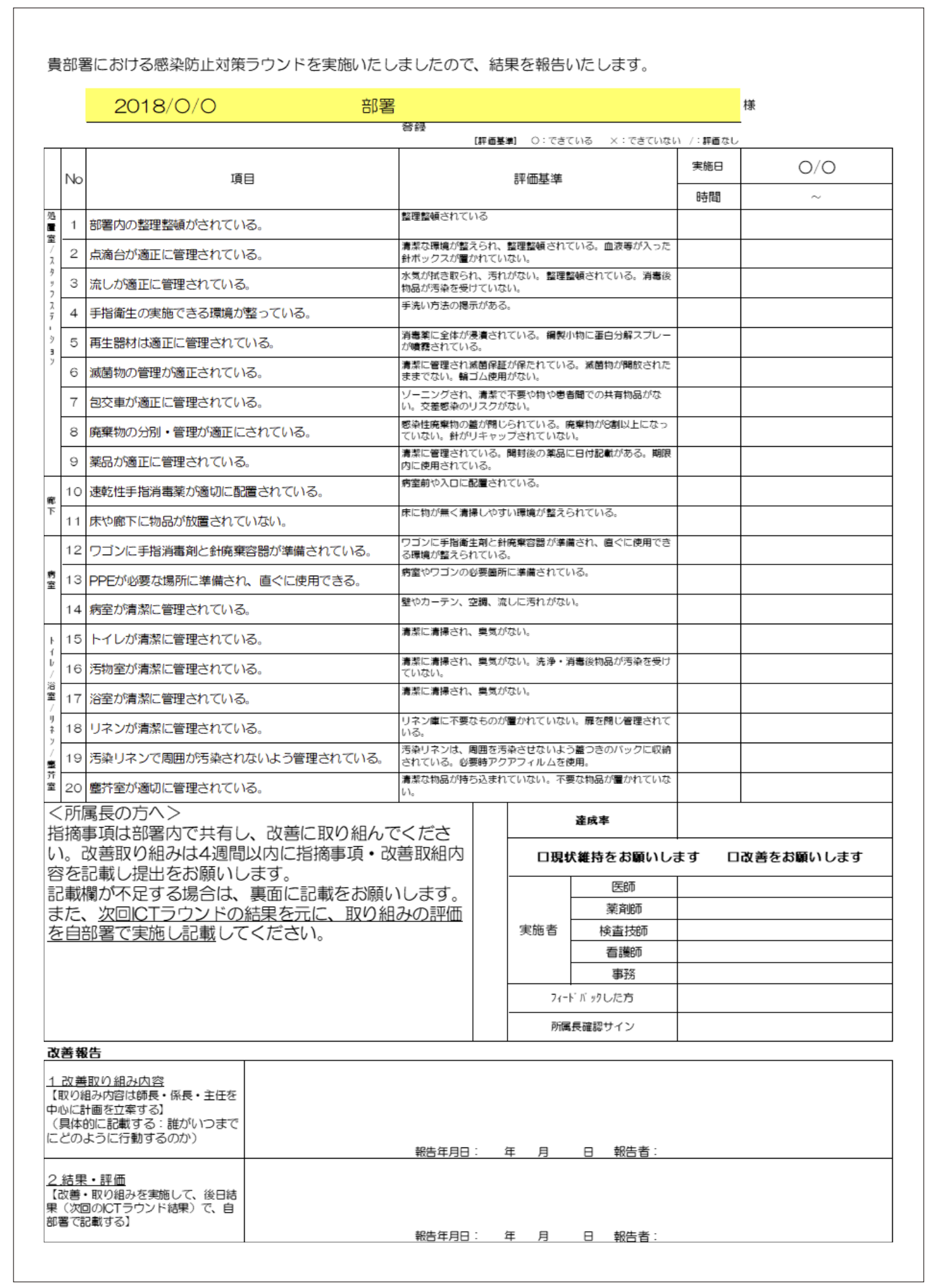

図 1 感染対策実施状況チェックシート

床上問題となる菌の分離率の関連性を検討した報告は少 ない.

済生会横浜市南部病院において, 感染制御チーム（In- fection Control Team：ICT）は院内感染防止対策とし て手指消毒薬使用率の向上に取り組み, 手指消毒薬の使 用率の変化と臨床上問題となると考えられる MRSA, 


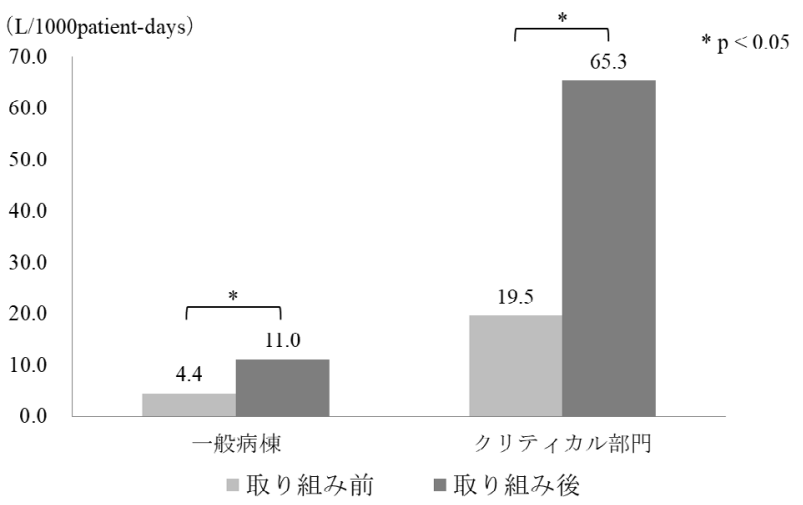

図 2 手指消毒薬使用率の推移

Serratia marcescens, 基質特異性拡張型 $\beta$ ラクタマー ゼ (Extended spectrum $\beta$-lactamases : ESBL) 産生大 腸菌の分離率の関連性を検討したので報告する。

\section{方法}

\section{1. 対象及び実施期間}

施設内 12 部署（一般病棟 10 病棟, クリティカル部門 (集中治療室, 新生児特定集中治療室)）を対象とし, 擦 式アルコール手指消毒薬の個人携帯および啓発活動の強 化を開始した 2016 年の前後 2 年間（以降， 2014 年 4 月 から 2016 年 3 月までを取り組み前, 2016 年 4 月から 2018 年 3 月までの取り組み後）において比較を行った。

\section{2. 手指消毒使用率向上に向けた取り組み}

1）擦式アルコール手指消毒薬の個人携帯開始

従来，各病室前に手指消毒薬を配置していた。 2016 年からは，それに加えて病棟で患者と接する機会が多い 看護師および看護助手に対して, 擦式アルコール手指消 毒薬を病室外に出なくても使用できるよう個人携帯を開 始した。

\section{2）啓発活動の強化}

各病棟内では手指消毒薬の個人使用量を可視化し, 病 棟単位での目標使用量達成率を月に 1 回院内全体に公開 した. 1 日 1 患者あたりの手指消毒薬使用目標量は, WHO 手指衛生ガイドライン $(2009)^{4)}$ に基づいて一般病 棟は $20 \mathrm{~mL}$ とした. なお，当院のルールとしてクリティ カル部門は $40 \mathrm{~mL}$ と設定した。 また, 病棟ラウンドを 週 1 回から 2 回へ増やし, チェックシートに沿って感染 対策実施状況の確認を行った（図 1)。病棟ラウンド時 には，標準予防策実施や耐性菌検出患者の経路別予防策 実施状況を確認した。手指消毒薬使用の夕イミングや個 人用防護具 (Personal Protective Equipment : PPE) の 適切な使用について直接指導を行った。 また, 感染管理 認定看護師による看護師への手指消毒実施状況のシャ ドーイングを行なった. さらに, 院内感染防止対策勉強 会を年 11 回開催し, その中で手指消毒に関連した内容
(手指衛生の手技，手指消毒剤の特性等）も取り入れ，職 員の知識向上に取り組んだ.

\section{3. 調査項目}

各項目に関して，一般病棟及びクリティカル部門にお いてそれぞれ算出し，取り組み前後での 1,000 患者延べ 日数あたりの手指消毒薬使用率および各菌の分離率の変 化を調査した。

\section{1）手指消毒薬使用率}

手指消毒薬使用率は，(入院病床手指消毒薬使用量 (L)/延べ入院患者数（人）×1,000）に基づき算出した.

\section{2）各菌の分離率}

MRSA, Serratia marcescens, ESBL 産生大腸菌の 各々の分離率は, (入院 48 時間以降に検出された分離患 者数/延べ入院患者数（人） × $1,000 ）$ に基づき算出した. また，分離患者数は，同一患者において複数の検査材料 から同一菌種が検出された場合には重複とみなし，それ を除外した。また，入院 48 時間以降に検出された場合 を院内伝播の対象とした ${ }^{10)}$.

\section{4. 統計処理}

手指消毒薬使用率と各菌の分離率との間の比較は, Student $\mathrm{t}$ 検定により解析を行い, $\mathrm{p}<0.05$ を有意差あり とした（使用統計処理ソフト JMP 10.0）.

\section{結 果}

取り組み前後における手指消毒薬使用率および各菌の 分離率を, 図 2 と 3 に示した. 手指消毒薬使用率 $(\mathrm{L} / 1,000$ patient-days）は, 取り組み前後において, 一般病棟で は 4.42 から $11.0 （ \mathrm{p}<0.05)$ ，クリティカル部門では 19.5 から $65.3(\mathrm{p}<0.05)$ 一増加した. MRSA 分離率（分離 数/1,000patient-days） は，取り組み前後において，一 般病棟では 0.58 から $0.35(\mathrm{p}<0.05)$, クリティカル部門 では 4.6 から 3.4 (p>0.05) へ減少した. Serratia marcescens 分離率（分離数/1,000patient-days）は，一般病棟 では 0.080 から 0.060 （p>0.05），クリティカル部門では 1.37 から $0.13(\mathrm{p}<0.05)$ 一減少した。 ESBL 産生大腸菌 分離率 (分離数 $/ 1,000$ patient-days) は, 一般病棟では 0.17 から $0.13(\mathrm{p}>0.05)$, クリティカル部門では 0.46 から 0.38 （p>0.05）と減少した.

\section{考察}

これまでに，手指消毒薬使用量のフィードバックや手 指消毒に関連した勉強会，ポスター掲示による啓発等が 手指消毒薬使用率の向上につながったとの報告があ る ${ }^{6,10)}$. 当院においても, 一般病棟およびクリティカル 部門の両部門において, 取り組み前と比較して取り組み 後には手指消毒薬使用率が増加していた. 手指消毒遵守 への取り組みとして, 病棟毎に手指消毒薬使用目標量を 明確化したうえで毎月情報共有を行い，院内感染防止対 


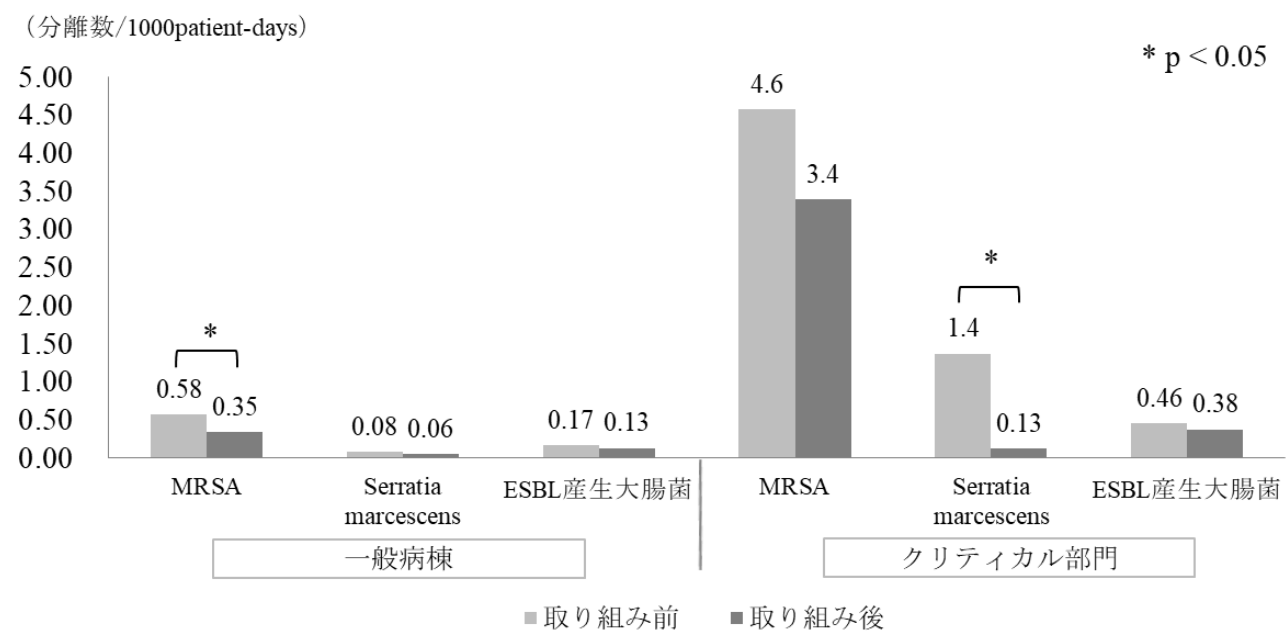

図 3 各菌の分離率の推移

策勉強会において適切な手指消毒薬の使用方法を指導し た。使用目標量と達成度の可視化や直接指導による職員 の感染対策に関する意識向上と, 手指消毒の必要性及び 消毒薬の知識習得により手指消毒薬使用率の向上につな がったと考えられる。また，感染管理認定看護師による 看護師の手指消毒実施の夕イミングのシャドーイングを 定期的に行ったことも，職員の意識向上につながったの ではないかと思われる.

標準予防策である手指消毒が MRSA 分離率に影響を 及ぼすことは数多くの報告がある ${ }^{5-8,11,12)}$ 。我々の検討で も, 一般病棟では手指消毒薬使用率の増加に伴い MRSA 分離率が有意に減少しており，本取り組みにより MRSA の院内伝播を抑制した。クリティカル部門では MRSA 分離率の有意差がなかった要因として, 取り組み後の対 象期間における NICUでのアウトブレイクが考えられ る。また，手指消毒薬使用率の増加により，Serratia marcescens および ESBL 産生大腸菌の分離率が減少し, Serratia marcescens のクリティカル部門での分離率に 関しては有意な差が得られた。 Serratia marcescens は, 水中や土壤等の自然界に広く分布し, 環境中では洗面所 や流し台といった湿気の多い場所に生息する。クリティ カル部門では呼吸器具等の使用頻度が多いことから Serratia marcescens の生息しやすい環境にあり，手指 消毒により菌の繁殖を抑えることができたのではないか と思われる. ESBL 産生菌は, 大腸菌, 肺炎桿菌, Proteus mirabilis 等の腸内細菌から多く検出されており, その 中でも ESBL 産生大腸菌は尿道留置カテーテルや粪便 の不適切な処理等により污染された環境から伝播するこ とが知られている。これらの菌の分離率の減少がみられ たことから, 手指消毒薬使用率向上は院内伝播を一定の 割合で抑制できた可能性があると考えている。これは, 手指衛生だけでなく ICT ラウンドによる感染対策の実
践状況確認や情報共有，現場での感染管理認定看護師の 直接指導により，手指消毒だけでなく $\mathrm{PPE}$ 等の標準予 防策が適切に実施された結果であると考えられる.

これまで主として病棟毎に看護師および看護助手を対 象として手指消毒の啓発活動を行ってきており，看護師 内の手指消毒率は上昇しているが，医師やメディカルス タッフに対しては十分であるとはいえない. カーテンゃ ボールペン，キーボード等の物品を介した院内伝播の可 能性も考慮すると, 患者と直接接触する職種以外にも積 極的に手指消毒の啓発活動が必要と考えられ，今後は ICT として看護師内の手指消毒薬使用率を維持すると ともに，全職種に対して感染対策の意識向上に努めてい きたい.

謝 辞 : 本論文の執筆にあたり，ご指導いただきました先生方 に深く感謝いたします.

本論文の主要な部分は, 第 34 回環境感染学会において発表し ました

利益相反自己申告：申告すべきものなし．

文献

1）國島広之：手指消毒薬の適正使用. 医療機器学 2009; 79(3): 120-5.

2）大久保憲：医療現場に打ける手指衛生。日本外科感染症学 会雑誌 2006; 3(4): 499-504.

3) Creamer E, Dorrian S, Dolan A, Sherlock O, FitzgeraldHughes D, Thomas T, et al: When are the hands of healthcare workers positive for methicillin-resistant Staphylococcus aureus? Journal of Hospital Infection 2010; 75(2): 10711.

4) WHO Guidelines on Hand Hygiene in Health Care: http:// whqlibdoc.who.int/publications/2009/9789241597906_eng.p df. accessed September 10, 2019. 
5) 嶋守一恵, 近藤啓子, 小野寺直人, 佐藤悦子, 諏訪部章, 櫻 井 滋：看護管理者を対象とした手指衛生向上プログラム の検証 : 手指消毒薬使用率と MRSA 発生率について. 環境 感染誌 2017; 32(5): 268-74.

6) 細川浩輝, 菊地志保子, 三星 知: 携帯式手指消毒薬導入 と使用量フィードバックの併用効果. 環境感染誌 2017; 32 (5): 263-7.

7) Jarlier V, Trystram D, Brun-Buisson C, Fournier S, Carbonne A, Marty L, et al: Curbing methicillinresistant Staphylococcus aureus in 38 French hospitals through a 15-year institutional control program. Arch Intern Med 2010; 170(6): 552-9.

8) Sroka S, Gastmeier P, Meyer E: Impact of alcohol handrub use on meticillin-resistant Staphylococcus aureus: an analysis of the literature. Journal of Hospital Infection 2010; 74(3): 204-11.

9）辻 明良, 李 秀華, 宮本 圭, 松菩英士, 宇良俊二, 遠 藤英子：MRSA, 腸球菌, O157, 七ラチア, 緑膿菌および
B.cepacia に対する消毒薬の最小殺菌濃度（MKC）と手指 消毒除菌効果. 環境感染誌 2002; 17(3): 268-74.

10) Garner JS, Jarvis WR, Emori TG, Horan TC, Hughes JM: CDC definition for nosocomial infections. Am J Infect Control 1988; 16: 128-40.

11）西岡達也, 岡本和恵, 井澤初美, 但馬重俊, 服部英喜 : 速 乾性手指消毒薬による手指衛生の遵守率向上への取り組み とその評価. 環境感染誌 2010; 25(1): 37-40.

12) Gordin FM, Schultz ME, Huber RA, Gill JA: Reduction in nosocomial transmission of drug-resistant bacteria after introduction of an alcohol-based hundrub. Infect Control Hosp Epidemiol 2005; 26(7): 650-3.

〔連絡先： ₹ 234-0054 神奈川県横浜市港南区港南台 3-2-10 済生会横浜市南部病院薬剤部 村田明子 E-mail: ako.61022@gmail.com]

\title{
Reduction in Bacterial Isolation Rate with Improved Compliance for the Use of Alcohol-based Hand Rub
}

\author{
Akiko Murata $^{1,2)}$, Kaoru KaWAShimA ${ }^{2)}$, Eiji HATAKeYAmA ${ }^{1,2)}$, \\ Ayaka YamaZAKi ${ }^{1,2)}$, Katsuki Matsumoto ${ }^{1,2)}$, Takashi FukAsAWA ${ }^{1,2)}$, \\ Natsuki Matsumoto ${ }^{2)}$, Akane KAmiYA ${ }^{2)}$ and Hiroyuki Fujita ${ }^{2)}$
}

${ }^{1)}$ Department of Pharmacy, Saiseikai Yokohamashi Nanbu Hospital, ${ }^{2)}$ Infection Control Team, Saiseikai Yokohamashi Nanbu Hospital

\section{Abstract}

A retrospective investigation was conducted to determine whether the use of an alcohol-based hand rub was correlated with the isolation rate of methicillin-resistant Staphylococcus aureus (MRSA) or Serratia marcescens and extended-spectrum beta-lactamase(ESBL)-producing Escherichia coli causing acquired nosocomial infection. To increase the use of alcohol-based hand rub, in 2014, we supervised the hand hygiene method used by each nurse and formed a study group to prevent nosocomial infection in each ward. In addition, we decided to make each nurse carry a personal alcohol-based hand rub from 2016. Thus, the usage rate for appropriate hand hygiene (L/1,000 patient days) increased from 4.42 to 11.0 in general wards and from 19.5 to 65.3 in critical departments before and after the approach. MRSA isolation rate (detection number/ 1,000 patient days) significantly decreased from 0.58 to $0.35(\mathrm{p}<0.05)$ in general wards and from 4.57 to 3.40 in critical departments. The rate of $S$. marcescens infection reduced from 0.08 to 0.06 in general wards and from 1.37 to 0.13 in critical departments $(\mathrm{p}<0.05)$. Moreover, ESBLproducing E. coli reduced from 0.17 to 0.13 in general wards and from 0.46 to 0.38 in critical departments.

To maintain a low bacterial isolation rate, we recommend educating and guiding nurses and all medical health professionals to more frequently use alcohol-based hand rubs.

Key words: hand hygiene, alcohol-based hand rub, MRSA, bacterial isolation rate 